\title{
Neo-liberalism and the Nordic welfare model: a study of the Liberal Alliance and ideological adaptation in Denmark
}

\author{
Troels Fage Hedegaard \\ Department of Political Science \\ Centre for Comparative Welfare Studies \\ Aalborg University \\ troelsfh@dps.aau.dk
}

\begin{abstract}
This article explores whether and how the neo-liberal ideology has adapted to the Nordic welfare model by studying the attitudes of voters and grass-roots members of the Danish party Liberal Alliance towards the welfare state. This inquiry into one of the key issues for the neo-liberal ideology is inspired by theory on how an ideology will adapt to its context. The expectation outlined in the article is for the neo-liberals of this party to favour features that make the Nordic welfare model distinctive - extensive governmental responsibility, especially for children and the elderly, and a universalistic approach to providing welfare. I have explored this question using a mixed-methods approach, where I analyse a survey of voters and interviews with grass-roots members of the party. Combined this shows that the neo-liberals in Liberal Alliance do support a role for the welfare state that extends beyond a minimum welfare state, especially for the care of children, but they view old age and retirement mostly as a problem each individual must deal with. Regarding the universalistic approach to providing welfare, the neo-liberals seem torn between two different tendencies, one being a perception of a fair way to provide welfare and the other the idea of a selective welfare state as a neo-liberal core idea, which leads to ambivalent attitudes. I argue that this results in a form of the neoliberal ideology that has adapted to the Nordic welfare model.
\end{abstract}

Keywords: neo-liberalism, liberalism, welfare, tax, Nordic, ideological morphology

\section{Introduction}

Over the last 30 years the neo-liberal ideology has gained considerable political influence across the world, including the Nordic countries (Saad Filho \& Johnston, 2004; Turner, 2008). The latest, and perhaps clearest, example of the neo-liberal ideology gaining a foothold in a Nordic country is the Danish party Liberal Alliance, which from 2008 onwards has successfully established itself on the political scene. In this article, I have sought to describe neo-liberalism in a Nordic country by studying the attitudes among the voters and members of this neo-liberal party. 
There is no single definition of what the term neo-liberalism covers, and there is great variation in how the term is used throughout the academic literature. According to Nielsen (2009), these definitions can be sorted into two fundamentally different camps, as some scholars use the term narrowly to describe an ideology, while others apply it in a broader and substantially different way to describe a situation of ideational hegemony (Peck, 2011) or a mode of governance, often inspired by Foucault (1988). In this article, I have used the term in its narrow definition to describe the ideology in its current form in a Nordic country.

This inquiry into the attitudes of Nordic neo-liberals was inspired by literature on how an ideology adapts to its context (Freeden, 1998; 2013; Turner, 2008). I have studied the adaptive capabilities of the neo-liberal ideology by focusing on the neo-liberals' attitudes towards the welfare state. Though the neo-liberal ideology informs attitudes towards a wide range of issues, the question of what the role of the state should be is, arguably, the key issue for the ideology (Gamble, 2013; Hartman, 2005). MacGregor (2005) argues that this focus on the state has developed because the neo-liberal ideology primarily arose in reaction to and in the context of the developing western welfare states. Similarly, the neo-liberal philosopher Hayek (1979) has described how the term liberal has shifted from describing a general attitude of mind to covering specific views about the proper function of government in its new form (Turner, 2008). The aim of this article has been to examine whether the neo-liberal ideology has adapted to the Nordic welfare model. The choice of focusing on this central aspect of the ideology has also resulted in this article drawing together two relatively different fields of study, as I have combined studies of attitudes towards the welfare state with theory of ideological adaptation. Though the two fields of study are normally separate from each other, this combination has been fruitful in the effort to describe neo-liberalism and its possible adaptation to the Nordic welfare model.

The rest of this section provides a description of the Liberal Alliance and neoliberalism in Denmark. The second section outlines the theoretical expectations of how neo-liberalism might adapt to the Nordic welfare model. The third section outlines the design of the study and the methods that have been applied. The fourth section presents the findings and the implications, and the fifth section discusses their limitations.

\section{Neo-liberalism in Denmark}

As a proportional-representation system, with a low barrier of two per cent of the votes, the Danish multiparty system is well suited to allow for the rise of protest movements and niche parties within the established political system. This has created a political system with high levels of change and volatility, as it was famously displayed in the 'landslide election' of 1973, where three new parties were elected to the parliament for the first time. The largest among these parties was Mogens Glistrup's Progress Party, which captured 16 per cent of the votes, partly on the back of neo-liberal anti-tax and anti-welfare rhetoric (Glans, 1984; Wilensky, 1975). This was the first instance of a party with a neoliberal streak gaining considerable public support in Denmark. The Progress Party later collapsed onto itself in the mid-1990s and transformed into the new right party, the Danish People's Party (Andersen \& Bjørklund, 1990). An important part of the Danish People's Party that rose from the ashes of The Progress Party was the transformation of the welfare policy from highly critical position to holding a more positive, though welfare-chauvinistic, perception of 
the welfare state (Rydgren, 2004). This left most of the neo-liberal voters to the more centrist Liberal Party, which throughout the period also housed a strong neo-liberal wing.

This was the state of neo-liberal ideology in Denmark until Liberal Alliance was founded in 2008 on the basis of a failed centre-right party, called New Alliance. Today the party has positioned itself as the strongest critic of the welfare state in the eyes of the voters (Stubager, Holm, \& Smidstrup, 2013), and though Liberal Alliance cannot be characterized as a single-issue party, it mainly drew attention from its messages critical of the welfare state. The party was first elected to parliament in 2011, with five per cent of the vote, though it already had members in parliament who jumped ship from other parties. They strengthened this position at the next parliament election in 2015, where they got seven per cent of the vote. This shows that, although Liberal Alliance is a niche party, it has gathered consistent support among the population.

\section{Adaptive neo-liberalism}

The theoretical argument I present in this section is that the neo-liberal ideology that Liberal Alliance represents has adapted to the Nordic welfare model. In order to do so, I shall draw on theories and studies of how ideologies adapt to a given context. Here the work of Freeden $(1998 ; 2013)$ is central, as it outlines how ideological adaptation, or ideological morphology, as Freeden $(1998 ; 2013)$ terms it, can be studied. This will be linked to literature on the Nordic welfare model in order to describe the context for neo-liberalism in a Nordic country.

According to Freeden (2013), the morphological approach stands in opposition to the idea that ideologies can be described solely as normative systems of ideas or through studies of significant of political thinkers throughout history. Instead, the approach argues for a different method where ideologies are studied through 'a ubiquitous practice, under-researched by political theorists, namely, that people in all walks of society think about politics in discernible patterns (...)' (Freeden, 2013, p. 115). These patterns of political thought, and how they might have adapted to the context of the Nordic welfare states, are central to the approaches applied in this article.

The first part of describing ideological adaptation is to define what an ideology is. Here a wide range of definitions can be outlined but, since I shall draw on the work of Freeden (1998), I shall also employ his definition of ideologies, which are the 'distinctive configurations of political concepts [...] that [...] create specific conceptual patterns from a pool of indeterminate and unlimited combinations' (p. 4). Ideologies are thus defined by the concepts that are at their 'core'. The core concepts make up the central ideas of the ideology, and thus cannot be abandoned without the existence of the ideology being threatened. The core concepts of an ideology are, however, translated into a given context through the 'adjacent' and 'peripheral concepts' (Freeden, 1998; 2013). The differences between the concepts can in some regard be likened to Hall's (1993) three orders of change, where the third-order or peripheral changes are common, while the first-order changes fundamentally alter the world view. By studying how the concepts are translated in a given context, Freeden $(1998 ; 2013)$ argues it is possible to study how an ideology adapts to a context. 


\section{Studies of neo-liberalism and ideological adaptation}

On the basis of Freeden's (1998) theoretical framework, Turner (2008) has tracked the formulations of neo-liberal thinking in Germany, the UK, and the US in the book Neo-liberal Ideology. Turner (2008) argues that the neo-liberal core concepts are a belief in the market, a general scepticism towards the welfare state, and an emphasis on the legal rights of the individual. The core concept of scepticism towards the welfare state, which is the main interest of this article, is then translated into adjacent concepts like support for a minimal state, equality of opportunity, negative rights, and personal responsibility. The adjacent concepts then give support for peripheral concepts like support for reduced social spending, workfare, and voucher systems. The peripheral concept is thus where the ideology meets policy and is adapted to the context. In accordance with the theoretical framework, Turner (2008) finds major differences in how the core concepts are translated into adjacent and peripheral concepts when comparing between countries and over time. Here Turner (2008) argues for large differences in perceptions of the welfare state between Germany and the US, because the German neo-liberalism has its roots in the tradition of ordoliberalism, which argues that a strong state is not contradictory to personal freedom, but often a precondition to it (Bonefeld, 2012).

Overall, this seems to support the idea that the neo-liberal understanding of the welfare state will develop differently, depending on its context (Turner, 2008, pp. 140-166). On the basis of the systematic finding of differences, Turner (2008) calls for 'varieties of neo-liberalism', where the neo-liberal perception of the welfare state varies with the institutional setup and size of the welfare state.

\section{Adaptation to the Nordic welfare model}

The countries in Turner's (2008) study, however, have welfare states that are qualitatively different from the Danish case, and, therefore, neo-liberalism in the Nordic countries may have adapted to a different context. To use EspingAndersen's welfare-regime typology, the countries are typical representatives of the liberal regime (the US and the UK) and the conservative regime (Germany). Denmark is, however, closer to Esping-Andersen's (1990) description of the social democratic regime. Since Esping-Andersen's typology of regimes refers to the historical actors mainly responsible for the welfare regime, I shall instead use the term 'Nordic welfare model' because it refers to the current institutional setup and further avoids the contradiction with respect to a 'social democratic neo-liberalism'.

The aim of this study has thus been to determine whether the Nordic welfare model has indeed had an impact on the attitudes of the neo-liberals in the Liberal Alliance. So how can the welfare regime affect neo-liberal ideology? According to institutional theory, this adaptation could happen through the welfare regime affecting what is perceived as the "normal state of affairs, and what it deviant and even impossible' (Svallfors, 2003, p. 172) with regard to the role of the government in the provision of welfare. A similar conclusion could be reached on the basis of the directional theory of issue-voting. This theory argues that the best strategy for a niche party is to place itself at an extreme point on the political scale in order to attract unhappy right-wing voters who seek the greatest impact of their vote (Kedar, 2005). The directional-voting theory, however, also contends that this extreme position should not be outside the 'region of acceptability', which is the socially accepted political space on the issue, because being perceived as 'extreme' or 'radical' will carry a harsh penalty from the voters (Rabinowitz \& Macdonald, 1989). The welfare regime should presumably affect what is perceived as normal and 'the region of 
acceptability', and thus neo-liberalism should be different in a Nordic country. In order to determine if this is the case, I needed a set of theoretical expectations. This is rather uncharted territory, but in trying to do this I have emphasized the three features that are common in the descriptions of the Nordic welfare model.

The first defining feature in the descriptions of the welfare states in the Nordic countries is the fact that the state has the key responsibility for the provision of welfare to the citizens. This has been described by scholars as 'Nordic stateness', as the state becomes the central authority in organizing how welfare goods are produced and according to which principles they are distributed (Kautto, 2010). Though most descriptions of neo-liberalism do reserve some role for the government in providing welfare for the very poorest, this goes far beyond the idea of a 'minimal state' (Hayek, 2014). Therefore, if there is an impact of the Nordic welfare model on their attitudes, there should be indications that the respondents support the idea that it is the government's responsibility to provide welfare.

Secondly, compared with other welfare state models, the greater responsibility of the state is especially prevalent within welfare service and care tasks (EspingAndersen, 1990; Kautto, 2010). A detailed breakdown of social-spending data from the OECD by Adema, Fron and Ladaique (2011) shows the areas where the Nordic countries especially differentiate themselves are on non-health welfare services, which cover care for children and the elderly. These two policy areas are thus especially interesting to examine, as they are areas where the state can take over tasks which otherwise could be argued to be a personal or family responsibility. If the neo-liberals argue that it is the government's responsibility to take care of these groups, it would thus support the idea of adaptation of the ideology.

The final feature of the Nordic welfare model that is common in the descriptions points to the fact that the Nordic welfare states distinguish themselves from other welfare states by awarding a comparatively larger degree of the welfare by the universal criteria (Castles, 2008; Esping-Andersen, 1990; Greve, 2007). A number of studies have shown that universal policies tend to generate larger public support (Jordan, 2013), in part because the recipients tend to be viewed more positively (Campbell, 2011). Thus, there should be indications of the universal policies being perceived as normal and part of what should be the government's responsibility (Svallfors, 2003). On the other hand, selective policies, targeted at the poorest, are normally considered to be a concept closely connected to neo-liberalism (Plant, 2010; Turner, 2008). Therefore, empirical support for universal over non-universal welfare programmes, and also for designing policies in a universal manner over a selective or targeted manner, would be a sign of adaptation of the ideology.

I have used the three criteria both to structure the analysis and to evaluate the results. Though these are not strict hypotheses, they have provided a sense of whether it is reasonable to argue for the existence of a neo-liberal ideology that has adapted to the Nordic welfare model.

\section{Research design and methods}

In order to study the proposed adaptation of the ideology, I used a mixedmethods design. This design combined a survey of attitudes towards the welfare state with five interviews with party 'grass-roots' members. This approach to studying the ideology was inspired by Skocpol and Williamson's (2012) 
investigation of the American Tea Party branch of the Republican Party. The authors argue that in order to provide a fuller description of attitudes and ideology of the members of the Tea Party, it is necessary to rely on a combination of methods in what adds up to a mixed-methods design: 'Interviews and ethnographic observations are also crucial for understanding what people's survey responses really mean, moving beyond crude characterizations...' (Williamson, Skocpol, \& Coggin, 2011, p. 27). This article has aimed for the same combination of an overview of their attitudes with an in-depth understanding of their reasoning.

\section{Methods}

The first part of the analysis was based on an election survey collected in the fall of 2011. The survey is the most comprehensive one covering attitudes towards the welfare state, and Liberal Alliance is also listed among the political parties. The survey was collected by YouGov among their online panel members after the election in November 2011. The survey included 6028 respondents, of which 333 voted for Liberal Alliance, which fits their overall support in the elections and polls of about five per cent at the time. There were enough respondents to run a meaningful analysis for comparing its voters with voters of other parties. The voters of other right-wing parties are especially interesting because this shows the degree to which voters of Liberal Alliance differ from the existing parties. It has been argued that there is a bias in respect of who participates in online surveys and panels, as the respondents tend to be younger, better educated, and interested in politics than the general population (Dennis, 2001; Sax, Gilmartin, \& Bryant, 2003). It is possible that this panel had higher rates of participation from more politically active and partly younger voters, though the biases are unknown. It was necessary, therefore, to be careful to read too much into the results.

The results of the survey were supplemented by five semi-structured interviews with members of local party committees in four cities. These local members of the parties are whom I call the 'grass roots' throughout the article. They performed a number of key tasks within their party, such as selecting the candidates for elections among their own ranks, organizing election campaigns, holding regular meetings, and much more. They thus constituted much of the life within the party. A total of five interviews is quite a small number to conduct, but the purpose of the interviews was not to describe the interviewees' attitudes towards the welfare state fully. Instead, the purpose of the interviews was to look into the reasoning behind the attitudes found in the survey, and possibly to explore the differences and ambivalences, and thus to help substantiate the survey results.

I conducted the interviews where it was most convenient and suitable for the respondents, and therefore these took place at a residence, a library, a university campus, and in the local parties' offices, among the election posters. The timing of the interviews coincided with a local election for the municipal government, and this meant that the grass roots were active but also somewhat difficult to get a hold of. Whether this affected who was available for the interview is difficult to determine, but it might have given me less access to the higherranking members. The interviews varied in length from 35 minutes to 1.5 hours, depending on how talkative the respondents were and how frequently the follow-up questions strayed from the interview guide. I found the respondents (referenced by their initials) by contacting all local committees via e-mail. I also collected simple descriptive statistics after the interviews in order to determine how representative the respondents were. However, since Liberal Alliance does 
not have any public record of their members, it is hard to judge this. On the basis of the election survey and their profiles, they compared reasonably well to the average voters. The largest divergence from the party was the fact that all respondents were men.

I analysed the interviews 'cutting' interviews into smaller parts and adding a coding structure to them, using the program Nvivo 10. This program enabled me to add one or more codes to each question and response and to search between the codes. For example, one question on whether the state should provide childcare was coded with the question, the respondent, and all the theoretically relevant concepts that came up in the answer. Using this structure of codes I could search between the answers and concepts in order to provide a better overview.

There are, however, also downsides to choosing this mixed-methods approach of combining surveys and interviews with different groups. First, it might be problematic to assume that the attitudes of the voters expressed in a survey show the attitudes and ideology of the party. The directional-voting theories argue that the strategy of niche parties is to take very extreme positions in order to attract attention (Meguid, 2005), which could lead to the voters being more centrist than the party. Secondly, by interviewing party grassroots members, instead of analysing party programmes and texts from political thinkers, I might have found formulations of the ideology that are less crystallized. In spite of these problems, I argue that this kind of study can give us insights that party programmes and texts from political thinkers cannot. It is more likely that not that texts and statements from professional politicians would be 'polished' to remove anything that might offend some voters. Therefore, the survey and interviews could provide insights that are closer to the attitudes to the real voters and the real debates within the party.

\section{Survey results}

For the survey-based part of the results, I shall present items on whether the government spends too much money, a suitable amount, or too little on several welfare policies. This measure can be interpreted as the overall support for or opposition to each welfare policy. To illustrate the support for each welfare policy further, I calculated the overall opinion balance by subtracting the percentage that answered 'too much' from the percentage that answered 'too little' was spent on the welfare policy. This produces a number ranging from +100 (all respondents found the spending level too low) to -100 (all respondents found the spending level too high). Respondents who answered that the spending is 'suitable' or who answered 'don't know' were included, but did not count as either for or against spending on the opinion balance. The results of this are presented in Table 1 below, with full details for Liberal Alliance. In order to contrast these results, I divided the other Danish parties into three groups: the traditional centre-right parties, consisting of the Liberal Party and the Conservative People's Party, the populist New Right Danish People's Party, and the left-of-centre parties. The last category could be subdivided further, but as the focus mainly is on Liberal Alliance, in comparison with the other right-wing parties, I have not done this. 
Table 1: Attitudes towards government spending on welfare policies, presented as opinion balances for groups of parties, with full details for Liberal Alliance.

\begin{tabular}{|c|c|c|c|c|c|c|c|c|}
\hline & Liber & I Allian & & & $\begin{array}{l}\text { Liber } \\
\text { al } \\
\text { Allian } \\
\text { ce }\end{array}$ & \multirow{2}{*}{$\begin{array}{l}\text { Traditio } \\
\text { nal } \\
\text { right- } \\
\text { wing } \\
\text { parties } \\
\text { Opinion } \\
\text { balance }\end{array}$} & \multirow{2}{*}{$\begin{array}{l}\text { Popul } \\
\text { ist } \\
\text { new } \\
\text { right }\end{array}$} & \multirow{2}{*}{ 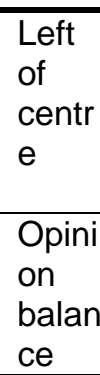 } \\
\hline & $\begin{array}{l}\text { Too } \\
\text { muc } \\
\text { h }\end{array}$ & $\begin{array}{l}\text { Suita } \\
\text { ble }\end{array}$ & $\begin{array}{l}\text { To } \\
o \\
\text { littl } \\
\mathrm{e}\end{array}$ & $\begin{array}{l}\text { Do } \\
\text { n't } \\
\text { kno } \\
\text { w }\end{array}$ & $\begin{array}{l}\text { Opini } \\
\text { on } \\
\text { balan } \\
\text { ce }\end{array}$ & & & \\
\hline Education & 5 & 44 & 45 & 6 & 41 & 34 & 35 & 66 \\
\hline $\begin{array}{l}\text { Homecare } \\
\text { for elderly }\end{array}$ & 9 & 47 & 34 & 10 & 25 & 35 & 63 & 57 \\
\hline $\begin{array}{l}\text { Healthcare } \\
\text { Childcare }\end{array}$ & $\begin{array}{l}13 \\
11\end{array}$ & $\begin{array}{l}44 \\
50\end{array}$ & $\begin{array}{l}38 \\
30\end{array}$ & $\begin{array}{l}5 \\
9\end{array}$ & $\begin{array}{l}25 \\
19\end{array}$ & $\begin{array}{l}35 \\
35\end{array}$ & $\begin{array}{l}64 \\
34\end{array}$ & $\begin{array}{l}67 \\
53\end{array}$ \\
\hline $\begin{array}{l}\text { State } \\
\text { pension } \\
\text { Unemploy }\end{array}$ & 19 & 51 & 17 & 10 & -2 & 18 & 49 & 35 \\
\hline $\begin{array}{l}\text { ment } \\
\text { insurance }\end{array}$ & 35 & 46 & 9 & 10 & -26 & -16 & -1 & 27 \\
\hline $\begin{array}{l}\text { Social } \\
\text { assistance }\end{array}$ & 52 & 33 & 7 & 8 & -45 & -36 & -20 & 20 \\
\hline
\end{tabular}

Notes: From a 2011 election survey. The traditional right-wing parties consist of the Liberal Party and the Conservative Party, the populist New Right party is Danish Peoples Party, and left-of-centre parties consist of The Social-Liberal Party, The Social Democrats, The Socialist People's Party, and The Red-Green Alliance.

$N$ (total) = Liberal Alliance (333), traditional right wing parties (1446), populist new right (624), left-wing parties (2966).

The results in Table 1 can be broken down in a number of ways. First, the results demonstrate the overall support for most of the welfare policies covered in the survey, as indicated by the positive opinion balances for most of the welfare policies. This overall support is much in line with Pierson's (1996) predictions of the welfare-state policies creating vested interests that sustain public support. There is also the expected difference between the left-wing parties and the parties on the right, where the opinion balance is positive for all policy areas for the left-wing parties, while the right-wing parties score negatively on unemployment insurance and social assistance. The results also show that there are major differences between the policy areas in respect of public support. These differences seem to fit the general finding that universal policies are more popular than selective ones, because public support is significantly greater for the universal welfare services in the form of education, homecare for the elderly, healthcare, and childcare (Jordan, 2013). Another possible interpretation of ranking between the policy areas is that while the more popular policies are targeted at groups that are universally found to be 'deserving' (the elderly and children), the less popular policies are targeted at the unemployed who generally are perceived as undeserving (van Oorschot, 2006). This concordance between the explanations might be due to the policy design fostering the perception that the recipient groups are deserving or undeserving (Campbell, 2011).

If we turn to the Liberal Alliance voters, there is a largely similar attitudinal pattern, with overall support for four of the seven policy areas. This is lower than the other party groups, but it still shows a degree of support for welfare spending. This indicates an acceptance of governmental responsibility, as the 
first criterion states, which goes far beyond a 'minimal state'. The results for Liberal Alliance voters also show that they are much more polarized between universal and non-universal policies than other groups. The policies awarded by the universal criteria are in the positive range (education, homecare for elderly, healthcare, and childcare), while the non-universal policies are in the negative range of the opinion balances. One deviation from this pattern of support among them for universal policies is the state pension. Here, they are split down the middle (opinion balance -2); most find the spending suitable, but 19 per cent of them find the spending too generous. This deviation from the pattern might be explained by reforms that have made the state pension more selective and less available to younger, high-income groups (Goul Andersen, 2011). A similar age effect on the attitudes towards state pensions is also present in other parties. Therefore, part of the negative attitudes towards this policy can be attributed to a disproportionate amount of younger voters (not shown). Regarding the two non-universal policies aimed at the unemployed, Liberal Alliance voters were by far the least supportive of spending, and in fact they supported retrenching both policies. This thus fits the third criterion of support for universal policies over selective policies. This does not necessarily mean that these voters rejected the idea of selective policies, but perhaps they felt that these were too generous. Finally, regarding attitudes towards the government's responsibility for the elderly and children, there is overall support for the government taking responsibility for care tasks (childcare and homecare for the elderly). This support, however, seems to co-exist with the lower support for the state pensions, the reason for which can be explored in the next section.

\section{Interview results}

What the survey cannot tell is why the neo-liberals expressed support for some welfare policies but not for others, and more generally, how they perceived the welfare state. This was the aim of the second part of the analysis, which was partially guided by the results above. I shall present the results of the interviews in three parts, following the criteria outlined in the theoretical section.

\section{'What we can rightfully call common goods'}

As the first criterion focuses on what the government should have in providing welfare, this part of the interviews focuses on what should be the responsibility of government and what should be left to the individuals to handle.

Though the respondents tackled this question differently, they, in one form or another, answered this by making distinctions between legitimate and illegitimate governmental tasks. The most descriptive version of this was made by $\mathrm{KL}$, who argued that the state should take responsibility for,

What we can rightfully call common goods. This is that which helps the country and society function and from which we all gain. This we get through the common purse, and the common purse is justifiably filled through taxes and fees.

Further defining the 'common goods', KL mentioned healthcare and education as examples of things that benefit all citizens and have a positive effect on society, and thus are justified. On the other hand, KL argued that areas in which welfare policies only benefit certain groups, or where the welfare state is in direct competition with private companies, should not be the government's 
responsibility. Other respondents made distinctions that were either wider or narrower with respect to what was included, but with a similar emphasis on universal welfare policies as legitimate.

The exception in this regard was FB, who argued that the government should take care of the 'core welfare areas' such as education, help for the sick, the disabled, and the involuntarily unemployed. Though this covers some of the same areas as outlined by $\mathrm{KL}$ above, this differs in the sense that instead of an opposition between universal and non-universal policy areas, he drew on the heuristics of deserving and undeserving groups (van Oorschot, 2000). However, no matter how the distinction of what should and should not be a governmental responsibility is drawn, this seems to extend far beyond a minimal state.

\section{'You have to presume that this is a personal responsibility, but...'}

The interviews also touched on more specific welfare tasks and whether these should be a responsibility of government. Following the second criterion outlined above, I was especially interested in attitudes regarding the government's role in taking care of the elderly and children.

As shown above in Table 1, there were somewhat mixed attitudes towards the government taking responsibility for the state pension. This attitude was also echoed in the interviews, as all respondents supported the idea that it should be the personal responsibility of the elderly to ensure their own living standards. As one of the respondents, TF, put it: 'You have to presume that this is a personal responsibility, since you can save for it over your lifetime'. Some of the respondents pointed to policy developments in the state pension, which have transformed into a multi-pillar pensions system (Goul Andersen, 2011) as the basis of this reasoning. This can be exemplified with $\mathrm{KL}$, who argued: 'I think we are making it a personal responsibility and that fits well with my way of thinking that you have to save for your own old age'. However, KL did not support full privatization of responsibility, for in the next sentence he added that: 'But again, those who do not save for their own retirement or for other reasons don't have anything; there I would like to see that they have a sort of minimum income'. KA argued similarly, but as in the discussion above with how to determine what should be a governmental responsibility, he kept underscoring how the recipients should be 'deserving', and if the recipients have not contributed to society in their lifetime, then they should not be helped.

On attitudes towards the responsibility of government for children, the attitudes were more mixed among respondents. One line of argument, provided by some of the respondents, mirrored the one for the elderly outlined above. For instance, FB argued: 'Why should I pay such high taxes, just so the state can give me money to have children. You can have all the kids you want, but you have to pay for them yourself'. On the other hand, FB also argued that the one area where he would support increasing government spending was for at-risk children. This follows the same logic of personal responsibility, but with a government-provided 'social minimum'. Other respondents did not seem to favour any changes, and thus perceived this as the normality: '[state-financed] kindergartens are fine; someone has to look after the children while you are at work, so that has to be a responsibility of the government'. Here the primary criticism focused on the lack of choice among private providers, but not with governmental responsibility itself.

Regarding the second criterion, the attitudes of the neo-liberals seem to support the idea that this should be a personal responsibility, but also that the state 
should step in when individuals fail. This was the most prominent attitude towards pensions for the elderly - a process possibly pushed along by policy reforms.

\section{'People want something back; it is only natural.'}

As outlined by the third criterion, the final part of the interviews focused on the question of whether welfare policies should be universal or targeted at specific groups (i.e., selective). As Table 1 displays, there is little overall support for the non-universal benefits among Liberal Alliances voters. However, what the survey cannot reveal is the reasoning behind this and what it is about the selective benefits they object to.

In the discussion of the welfare state generally, and the selective benefits in particular, the respondents kept returning to one core critique, namely, the distortion of incentives. The respondents argued that many people are unemployed not because they are unwilling to work, but because they do not have the incentive to work. The respondents thus did not blame people for not having the will to work, but instead pointed to the structures of incentives created by the welfare state. As FB, very directly, put it: 'People are not stupid. They will not work for less than what social assistance pays'. KL, who is an employer himself, also argued that there are many of the unemployed whom he cannot hire: 'Many of these people just aren't valuable enough', with reference to paying them more than social assistance. The unemployed are, in the respondents' perception, not lazy, but instead rational actors who chose not to work. This also leads them to a clear solution to the problem: social benefits have to be retrenched in order to give the low-skill unemployed enough incentive to work. At the heart of their world view seems to be an 'economicman' logic, which came through in the interviews (Plant, 2010). This logic of 'economic man' seems to clash with the structures of incentives created by selective benefits, what have also been called 'poverty traps'. This logic thus seemed to help explain both the apparent support for universal benefits and the rejection of non-universal benefits displayed in Table 1.

This was also what I found when I asked whether the welfare-state benefits should increasingly be targeted. Here the respondents displayed general support for the idea, coupled with scepticism about whether it was possible and in some cases desirable. An example of this was NN, who argued: 'This is what the welfare state should do-help the poor'. He added: 'It is okay to help the rich and the middle classes, and that has to remain'. Similarly, $\mathrm{KL}$ argued:

If you exclusively make a community that most people pay into and which more or less ensures that people are not dying in the streets or helps the sick and handicapped, then people would not support it. People want something back; it is only natural.

The respondent FB outright rejected the idea of a more targeted welfare state: ' (...) it is not an either-or proposition. In an area like healthcare it is fine to finance it commonly, since it can affect anyone. [This is] similar to unemployment. Here it makes no sense [to target the welfare].' Altogether, I would argue that this adds up to a set of attitudes that can best be described as ambivalent. On the one hand, the respondent seemed to support the principle of targeting; on the other hand, the respondent also underlined the positives of universalism within a range of welfare tasks. 


\section{Limitations and implications}

In this article, I have put forward the claim that the neo-liberal ideology in the Nordic countries has adapted to the Nordic welfare model. This claim is inspired by Freeden's (1998) morphological theory on how ideologies adapt to a given context and create a distinct form of the ideology. In order to study this, I have focused on the neo-liberal perception of what the role of government should be, and whether this has adapted to the context, which in this case is the Nordic welfare model.

I studied these questions by focusing on the Danish political party Liberal Alliance, which is the newest iteration of a neo-liberal party in a Nordic country. Following the morphological approach, I tracked the attitudes of voters of the party and 'grass-roots' members towards the role of government and the welfare state. This mixed-methods approach, drawing on both a survey and interviews, provides a different approach to studying ideological change, and it has yielded some valuable insights. Nevertheless, there are some shortcomings, and thus it might be problematic to assume that the voters or the 'grass roots' can fully capture the ideological position of the party on the issue of the welfare state. In spite of these clear limitations in what the methods can capture I argue that I find some impact on the neo-liberal understanding of the role of government.

In this regard, the concept of universalism was especially interesting because it seemed to create a strong ambivalence between the neo-liberal idea of targeting and the support that universalism tends to create. This result is very close to what Williamson and Skocpol (2012) have found in their study: 'Tea Partiers favour generous social benefits for Americans who "earn" them; yet in era of rising federal deficits, they are very concerned about being stuck with the tax tab for "unearned" entitlements handed out to unworthy people' (p. 56). This ambivalent relationship to the welfare state, and the constant search for deserving and undeserving groups, is perhaps the product of an ideology that is critical to the welfare state which has been fostered in the age of big governments.

I believe that this is not a result unique to the Nordic counties and the Nordic welfare model, and, in fact, following the idea of morphology, we can expect distinct versions of the ideology in all welfare regimes (as also shown by Turner, 2008). This also helps to provide a clue about how the regimes remain distinct in the face of the increasing pressures resulting from neo-liberalism, which some researchers (Hall \& Lamont, 2013; Saad Filho \& Johnston, 2004) predict will spark a 'race to the bottom', where the welfare states will increasingly retrench and become more alike. The literature on the impact of welfare models often argues that the stability of the regimes is caused by 'lock-in effects', where the current institutional set-up over time reinforces decisions to remain within this path, since welfare reforms seem politically impossible because of the high economic costs that changing paths would involve (Pierson, 2001). Béland (2010), however, argues that the lock-in effect can also be of an immaterial nature, and that the studies of welfare states have focused too much on the material lock-in effects. The finding of an adapted neo-liberalism could be one such immaterial lock-in effect. 


\section{References}

Adema, W., Fron, P., \& Ladaique, M. (2011). Is the European welfare state really more expensive? (Working paper No. 124). OECD Social, Employment and Migration Working Papers: OECD publishing.

Andersen, J. G., \& Bjørklund, T. (1990). Structural changes and new cleavages: The progress parties in Denmark and Norway. Acta Sociologica, 33(3), p. 195-217.

Béland, D. (2010). Reconsidering policy feedback. Administration \& Society, 42(5), p. 568-590.

Bonefeld, W. (2012). Freedom and the strong state: On German ordoliberalism. New Political Economy, 17(5), p. 633-656.

Campbell, A. L. (2011). Policy feedbacks and the impact of policy designs on public opinion. Journal of Health Politics, Policy and Law, 36(6), p. 961-973.

Castles, F. G. (2008). What welfare states do: A disaggregated expenditure approach. Journal of Social Policy, 38(1), p. 45-62.

Dennis, J. M. (2001). Are internet panels creating professional respondents? Marketing Research, 13(2), p. 34-46.

Esping-Andersen, G. (1990). The three worlds of welfare capitalism. Cambridge: Polity Press.

Foucault, M. (1988). Technologies of the self: A seminar with Michel Foucault. Amherst: University of Massachusetts Press.

Freeden, M. (1998). Ideologies and political theory: A conceptual approach. Oxford: Oxford University Press.

Freeden, M. (2013). The morphological analysis of ideology. In M. Freeden, L. Sargent \& M. Stears (Eds.), The Oxford handbook of political ideologies (p. 115-137). Oxford: Oxford University Press.

Gamble, A. (2013). Economic libertarianism. In M. Freeden, L. Sargent \& M. Stears (Eds.), The Oxford handbook of political ideologies (p. 405-421). Oxford: Oxford University Press.

Glans, I. (1984). Fremskridtspartiet - småborgerlig revolt, högerreaktion eller generell protest? [The Progress Party - petty bourgeois revolt, right wing reaction, or general protest] In I. Elklit O. (Ed.), Valg og vælgeradfærd (p. 195-228). Århus: Politica.

Goul Andersen, J. (2011). Denmark: The silent revolution toward a multipillar pension system. In B. Ebbinghaus (Ed.), The varieties of pension governance: Pension privatization in Europe (p. 183-209). Oxford: Oxford University Press.

Greve, B. (2007). What characterise the Nordic welfare state model. Journal of Social Sciences, 3(2), p. 43-51.

Hall, P. A. (1993). Policy paradigms, social learning, and the state: The case of economic policymaking in Britain. Comparative Politics, 25(3), p. 275-296.

Hall, P. A., \& Lamont, M. (2013). Social resilience in the neoliberal era. New York: Cambridge University Press.

Hartman, Y. (2005). In bed with the enemy: Some ideas on the connections between neoliberalism and the welfare state. Current Sociology, 53(1), p. 57-73.

Hayek, F. A. (1979). Law, legislation and liberty: A new statement of the liberal principles of justice and political economy. Chicago: Chicago University Press. 
Hayek, F. A. (2014). The meaning of the welfare state. In C. Pierson, F. G. Castles \& I. Naumann (Eds.), The welfare state reader (3rd ed., p. 90-95). Cambridge: Polity.

Jordan, J. (2013). Policy feedback and support for the welfare state. Journal of European Social Policy, 23(2), p. 134-148.

Kautto, M. (2010). The Nordic countries. In F. G. Castles, S. Liebfried, J. Lewis, H. Obinger \& C. Pierson (Eds.), The oxford handbook of the welfare state (1st ed., p. 586-600). Oxford: Oxford University Press.

Kedar, O. (2005). When moderate voters prefer extreme parties: Policy balancing in parliamentary elections. American Political Science Review, 99(02), p. 185-199.

MacGregor, S. (2005). The welfare state and neoliberalism. In Saad-Filho. A, \& Johnston. D (Eds.), Neoliberalism: A critical reader (pp. 142-148). Ann Arbor: Pluto Press.

Meguid, B. M. (2005). Competition between unequals: The role of mainstream party strategy in niche party success. American Political Science Review, 99(03), p. 347-359.

Nielsen, P. (2009). Nyliberalismen i velfærdssamfund [Neo-liberalism in the welfare society]. In A. Lundkvist (Ed.), Dansk nyliberalisme (1st ed., pp. 95). København: Frydenlund.

Peck, J. (2011). Constructions of neoliberal reason. Oxford: Oxford University Press.

Pierson, P. (1996). The new politics of the welfare state. World Politics, 48(2), p. 143179.

Pierson, P. (2001). The new politics of the welfare state. Oxford: Oxford University Press.

Plant, R. (2010). The neo-liberal state Oxford University Press Oxford.

Rabinowitz, G., \& Macdonald, S. E. (1989). A directional theory of issue voting. The American Political Science Review, 83(1), p. 93-121.

Rothstein, B. (1998). Just institutions matter: The moral and political logic of the universal welfare state Cambridge University Press.

Rydgren, J. (2004). Explaining the emergence of radical right-wing populist parties: The case of Denmark. West European Politics, 27(3), p. 474-502.

Saad Filho, A., \& Johnston, D. (2004). Neoliberalism: A critical reader. London: Pluto Press.

Sax, L. J., Gilmartin, S. K., \& Bryant, A. N. (2003). Assessing response rates and nonresponse bias in web and paper surveys. Research in Higher Education, 44(4), p. 409-432.

Skocpol, T., \& Williamson, V. (2012). The Tea Party and the remaking of Republican conservatism. Oxford University Press.

Stubager, R., Holm, J., \& Smidstrup, M. (2013). Danske vælgere 1971-2011. En oversigt over udviklingen $i$ vælgernes holdninger mv [Danish voters 1971-2011. An overview of the developments in the voters attitudes etc.]. Århus: Århus Universitet.

Svallfors, S. (2003). Welfare regimes and welfare opinions: A comparison of eight western countries. Social Indicators Research, 64(3), p. 495-520.

Turner, R. (2008). Neo-liberal ideology Edinburgh University Press Edinburgh.

van Oorschot, W. (2000). Who should get what, and why? On deservingness criteria and the conditionality of solidarity among the public. Policy \& Politics, 28(1), p. 33-48. 
van Oorschot, W. (2006). Making the difference in social Europe: Deservingness perceptions among citizens of European welfare states. Journal of European Social Policy, 16(1), p. 23-42.

Wilensky, H. (1975). The welfare state and equality: Structural and ideological roots of public expenditure. Berkeley: University of California Press.

Williamson, V., Skocpol, T., \& Coggin, J. (2011). The Tea Party and the Remaking of Republican Conservatism. Perspectives on Politics, 9(1), p. 25-43 